\title{
The Implications of Economic Change in Indonesia for Social Class Formation
}

\author{
Anne Booth | ORCID: 0000-0002-5360-1251 \\ soAs University of London, London, UK \\ abro@soas.ac.uk
}

\begin{abstract}
This article investigates the relationship between economic growth and changing class structures in Indonesia over the last century, with particular emphasis on the postindependence decades. Investigations carried out in the colonial era found that access to land and to government employment were crucial determinants of both income and social status. After 1950, these factors continued to be important, but in addition some studies also examined the growth of the private sector outside agriculture and its implications for changing social stratification among indigenous Indonesians. In recent times, contributions to the literature on the middle class have been made by international agencies (such as the Asian Development Bank and the World Bank). These studies have defined the middle class in terms of household income or expenditures and have argued that the middle class in Indonesia is growing and is now larger than the number of people living in poverty. The implications of this for future government policies are discussed.
\end{abstract}

\section{Keywords}

class formation - social stratification - Indonesia - colonial period - postindependence

This article reviews analyses of class in Indonesia in the light of the considerable changes that have occurred in the Indonesian economy and society since the 196os. Four trends are singled out as especially important: rapid urbanization, a decline in the agricultural sector as a source of income and employment in many parts of Indonesia, a growth in the proportion of the labour force 
with upper secondary and post-secondary education, and a decline in government expenditure as a proportion of GDP. These changes reflect an ongoing structural change in the economy: the share of the agricultural sector in total output has fallen and that of industry and services has grown. The 2010 Population Census classified half of all households as urban, while the 2019 labour force survey found that $27 \%$ of the labour force gave agriculture as its primary source of income, compared with $56 \%$ in 1980 . Data from successive censuses and labour force surveys have found that a growing proportion of employed workers, both male and female, have at least upper secondary education. At the same time, the ability of the government to mobilize resources through taxation and other means appears to have declined relative to national income. What are the implications of these trends for class structures? Several studies have attempted to quantify changing stratification in Indonesia, in particular the growth of the middle class. A World Bank study, using household expenditures as the determinant, claimed that by 2016 the middle class was larger than the group classified as poor. This study also quantified the size of the aspirational middle class and discussed the implications for government policies of these findings. The implications of these choices are discussed in the final part of the article.

\section{Debates over Class Structure in the Colonial Era}

Debates about class structure in Indonesia can be traced back to at least the early twentieth century, when elements within the nationalist movement made contact with socialist activists in the Netherlands (Farid 2005:175). In response to concerns over inequalities in income and tax burdens, several investigations were carried out over the 1920s, the best known being the study of Meijer Ranneft and Huender (1926). This study found evidence of large income disparities within the indigenous population of Java in both urban and rural areas. The depression of the early 193 os led to further changes in incomes, both on Java and elsewhere. Jobs as wage labourers on Java and Sumatra contracted as a result of falling international demand for tropical products and growing global protectionism. Government responses were constrained by falling budget revenues, but there was an increase in the proportion of Indonesians in the civil service. Kahin (1952:35) showed that by 1938, Indonesians accounted for almost all personnel in the lowest grades and $61 \%$ of those in the lower-middle grades. Very few made it to the highest grades, where Europeans dominated. Indigenous Indonesians were usually employed at lower salaries than Dutch officials, even if they were doing similar work, which inevitably caused resentment. 
But the expansion of opportunities in government employment was not rapid enough to absorb the entire output of the Dutch-language school system, small though that output was relative to the population. Kahin argued that many found work as teachers in the private 'wild schools', whose numbers grew after 19oo. That expanded access to education acted as 'dynamite on the colonial caste system' as Wertheim (1956:128) claimed, seems unlikely, given the small numbers involved. But as more schools were opened, most of which did not offer Dutch-language tuition or chances of progression beyond the primary level, they created new expectations. There was growing frustration on the part of many young people who found that the skills they had obtained did not lead to the prestigious jobs they expected, either in government or in the private sector. These frustrations were found outside Java as well; Schrieke (1966:160) found them widespread in West Sumatra, where young people had overestimated the value of the schooling they had received.

In his analysis of social and economic change in the final decades of Dutch colonial rule, Kahin (1952:29) argued that the Indonesian middle class that emerged in these years was 'predominantly non-capitalistic' and 'for the most part consisted of salaried employees', many of whom were civil servants and teachers. But Wertheim (1956:124-5) took issue with Kahin's assertions that, in the final decades of Dutch colonialism, the Indonesian commercial class was small and probably declining in numbers as a result of Chinese and European competition. He argued that on Java the percentage of employed Indonesians involved in trade had probably increased between 1905 and 1930. Mertens (1978: Appendix Table 1.6) found that over one million Indonesians were engaged in trading activities in 1930; in parts of Java, many were women. It is probable that some of those enumerated as working in agriculture in the 1930 census were also engaged in trading activities for at least part of the year. Outside Java, especially in parts of Sumatra, the growth of smallholder production of cash crops also led to growing involvement in marketing activities. While large-scale trading activities might have been dominated by Chinese and European firms, indigenous operators also emerged from the ranks of those who had managed to gain some literacy and numeracy in the school system (Wertheim 1956:128-30). He argued that in some parts of Sumatra, including the Minangkabau lands, Chinese traders never got a foothold. ${ }^{1}$

1 Lev (1990:31-2) argued that some young men from upper-class backgrounds opted out of careers in the civil service in favour of independent careers as professionals. Such choices were probably easier for Sumatrans than Javanese, because of higher literacy and better commercial opportunities among Minang and Batak populations in particular. Although literacy rates among the population over 10 were only around $47 \%$ in Indonesia in 1961 , they were 
Wertheim did however acknowledge that even a lowly clerk working in an urban enterprise had greater social prestige than a skilled farmer, whether growing food crops or export crops, even if the clerk's income was the same or lower. Access to education 'created a new class of intellectuals and near intellectuals who occupied a special position in society' (Wertheim 1956:126). But alongside this class was a much larger group of Indonesians who by the $1930 \mathrm{os}$ had learnt new skills as metal workers, mechanics, engine drivers, and overseers as well as employees in large-scale manufacturing enterprises and in government enterprises such as pawnshops. Certainly by 1940, Indonesian society had become more diverse, and new classes based on individual achievement were evolving. They did not replace the older systems of social stratification based on family background or on ethnicity, but some of those who had managed to get some education rose to responsible positions under the Japanese and during the independence struggle.

The Japanese occupation, although short in duration, had important consequences for the social stratification that had evolved in the colonial era. The Dutch had been humiliated by an Asian army. The occupation forces killed or incarcerated most Dutch citizens and promoted Indonesians to more responsible jobs in the civil service. But as economic shortages became more serious, many Indonesians became disillusioned with the Japanese. When the Dutch returned in the wake of the British army in 1945, they found a mutinous population that was determined not to allow a restoration of the pre-1942 system. Four years of bitter fighting followed before the Dutch were pressured into recognizing the independence declared by Sukarno and Hatta in August 1945 .

The economic conditions which faced the new republic were in several respects more serious than those which faced the Philippines, India, Pakistan, and Sri Lanka, all of which had been granted independence in 1946 and 1947. Real per capita GDP in Indonesia in 1949 was only about $64 \%$ of that in 1941; there was some recovery after 1950, but Indonesia was still below the 1941 level in 196o (Van der Eng 2013). The struggle for independence had created expectations on the part of many Indonesians that their living standards would improve, which successive cabinets, struggling with reduced resources, could

higher for both men and women on Sumatra than on Java (excluding Jakarta) or on islands other than Java (Nugroho 1967:142). 
not meet. Those Indonesians who had managed to get employment in government service in the Dutch era had often been promoted into more responsible jobs after 1942 and formed the core of the new civil service after 1950. Many local government officials (bupati, wedana, camat, lurah) also kept their positions, especially on Java, often with enhanced prestige if they were seen to have supported the republican cause. The structure of regional and local government on Java remained largely unchanged, although there were major changes in Sumatra and other parts of the country. ${ }^{2}$ The civil service grew after 1950; the lower ranks were often filled with men who had fought against the Dutch, even if they lacked much education or technical skills. In real terms, salaries were usually lower than in the late colonial era. While senior civil servants probably enjoyed considerable prestige in the 1950s, their official salaries only allowed a fairly modest standard of living. The temptation to look for extra sources of income grew over the 195 os.

By 1961, slightly more than one million Indonesians were employed in the civil service, which was around $11 \%$ of the non-agricultural labour force, as enumerated in the 1961 Population Census. ${ }^{3}$ What other employment opportunities were available? Most of the non-agricultural labour force was employed in manufacturing, trade, and other services (Nugroho 1967:116). In an early examination of the emergence of the post-independence middle class, Van der Kroef (1956:31) argued that the 'middle class in Indonesia is for practical purposes identical with the entrepreneurial element'. He distinguished five categories of middle-class Indonesians engaged in non-agricultural private enterprises. The first two were those who ran industrial and trading enterprises, mostly small-scale and usually precarious, not least because of competition from Chinese and Arab businesses. The third group consisted of Indonesians who were truly enterprising and moved into a range of transport enterprises, using trucks, buses, boats, motor-tricycles, and carts. They performed a crucial function, especially outside of Java, in moving both goods and people. The last two categories were mainly urban; one consisted of small artisans with their own shops, engaged in the fabrication and resale of consumer goods includ-

2 Outside of Java, provinces and sub-provincial levels of government had to be created where none had existed before; the new units were often arbitrary and created resentment among local populations (Booth 2010). In spite of the growth in the civil service that took place after the 1950s, total numbers on the government payroll comprised only about $1 \%$ of the population in 1961, which was a lower percentage than that in Malaysia or Thailand (Evers 1987: Table 1).

3 Numbers employed by central and regional governments and also by state enterprises in 1961 are given in Biro Pusat Statistik (вPS, Central Bureau of Statistics) (1968:30-2). Nugroho (1967:116) gives labour force figures from the 1961 Population Census. 
ing food and clothing, furniture, radios, and other household goods. The last group was the professional middle class (doctors and trained health workers, lawyers, university lecturers, and teachers), which was small in absolute terms because so few Indonesians had been able to access higher education before 1942. However, its political influence was far out of proportion to its numbers. Those with legal training in particular were often prominent political leaders in the early years of the republic.

Van der Kroef's analysis can be criticized as rather limited in scope; he appears to have ignored the entrepreneurial elements of those within agriculture who were producing a range of products for both national and international markets and were also moving into trading and transport enterprises, often with hired labour. Nor did he tackle the problem to which Geertz (1963:28) drew attention in his studies of small towns on Java and Bali. Geertz argued that many Muslim businessmen in the town of Pare in East Java were trapped in the small-scale pasar economy, unable to build larger firms run along capitalist lines. By the late 195os, the deteriorating economic situation made running a business more difficult for all ethnic groups. The Chinese and Arab traders often had access to credit that was not available to small indigenous businesses, which allowed their businesses to survive, if not flourish.

In the early 195os, the government embarked on the Benteng programme, which tried to develop indigenous businesses, especially in the import sector, by giving them access to scarce foreign exchange at the official, over-valued rate. The results were not encouraging, and critics argued that the policy gave rise to so-called Ali Baba firms, fronted by politicians and others who could access foreign exchange and credit but in effect managed by Chinese who had the contacts in Singapore and elsewhere to import consumer goods. But as Lindblad (2010:105-8) argued, not all the firms that were established after $195^{\circ}$ by indigenous Indonesians were Ali Baba enterprises and it was possible to find examples of new enterprises created by businesspeople of both Sumatran and Javanese origin. His examination of large, indigenous firms in 199 o found that at least one quarter had their origins in the 1950s or earlier. In several cases, these firms had benefited from close family links to senior political figures, but they had managed to survive after their patrons had left office.

It is probable that, had different economic policies been followed after 1957, the Indonesian economy could have avoided the serious problems of the next decade that led to economic stagnation, mounting inflation, and widespread poverty. A substantial indigenous entrepreneurial class could have emerged. Instead, the government favoured policies that were hostile to private enterprise. In spite of much rhetoric about 'Indonesian socialism' on the part of Sukarno and other ministers, the years from 1957 to 1967 saw a steady decline in 
government control over the economy. Although economic plans were drawn up, they were not implemented because of inadequate funding and shortages of foreign exchange, which made it difficult to procure capital equipment. Skilled workers were often in short supply. Most of the projects in the sevenyear plan, scheduled to run from 1961 to 1968 , were never implemented (Booth 1998:173-4). Effective planning only began with the first five-year plan of the Soeharto era.

Van der Kroef (1956:41) argued that a process of polarization of wealth was already underway in the early post-independence years and was leading to sharper class stratification. In rural areas, he claimed that a class of absentee owners was emerging which 'owned considerable acreage, under the care of managers'. There was also a growing class of rural people who owned little or no land and were dependent on labouring income for their survival. He had little statistical evidence to support these arguments; it was only when the 1963 Agricultural Census became available that some data became available on size distribution of holdings. They showed a rather skewed distribution of smallholder agricultural holdings: the top $5 \%$ of operated holdings controlled almost one third of all land while the bottom $40 \%$ controlled only $10 \%$ (Booth and Sundrum 1976: Table 8). While the average holding size, excluding large estates, was around one hectare for Indonesia as a whole, a minority controlled much larger holdings. In Java, around $26 \%$ of land was not owned by the operator; $7 \%$ (almost 400,ooo hectares) was used to compensate village and other officials. In addition, it was estimated that 1.7 million hectares was controlled by large estates in 1963; by that year, most estates had been nationalized and converted into government enterprises.

The Chinese minority continued to attract attention in the 1950s, although its changing economic role was not easy to document, given the reluctance of the government to publish data broken down by ethnicity. Many Chinese continued to operate small businesses in wholesale and retail trade and experienced open hostility from some politicians. On the other hand, those who formed 'Ali Baba' enterprises with prominent politicians were able to withstand the pressures of indigenism; often they used their political contacts to buy up businesses left by the departing Dutch (Anspach 1969:182). The 1961 Population Census did not ask questions about ethnicity, so it was not possible to estimate the number of Chinese remaining in Indonesia, or their occupations. But their numbers were small, at most 2.5 million. This, together with their dependence on political patronage, led some to argue that by the end of the 1950s the pre-war stratification according to race, already weakened during the Japanese occupation, had suffered a death blow. Wertheim (1956:138-9) argued that a new indigenous middle class consisting of officials, employees 
in non-agricultural enterprises, professionals, and technical workers was now dominant. ${ }^{4}$ Unlike in the Philippines, there was only a small mestizo class in Indonesia, resulting from intermarriage between Chinese, Dutch, and indigenous Indonesians, and they did not control large landholdings or many nonagricultural enterprises. When Dutch, British, and Belgian estates and other companies were nationalized after $195^{8}$, they became state enterprises, conferring new power and prestige on their managers, many of whom had a military background.

After 1958, with the introduction of Guided Democracy, the central government showed little interest in strengthening macroeconomic management. Mounting economic problems led to spiralling inflation and an over-valued exchange rate, which in turn caused widespread smuggling from Sumatra and elsewhere. While farmers producing export crops may have benefited from what amounted to the break-up of the national economy, many wage workers on estates faced sharp declines in real wages. Farmers with a surplus of rice and other food crops benefited from rising prices, but the great majority of rural families, especially on Java, were reliant on wage labour for at least part of their income. They had to buy food for most of the year and faced falling real incomes. The Communist Party exploited the grievances of both wage workers and those rural households with little or no agricultural land. Their membership and that of affiliated organizations rose rapidly. ${ }^{5}$

The official rhetoric of Sukarno and his key ministers in the early 196os emphasized Indonesian socialism, although what was meant by this term was not clear. Sukarno himself put forward the 'Marhaenist' ideology, which seemed to put all Indonesians into a single class which was 'exploited by and hostile to foreign capitalism' (Castles 1965:15). Castles argued that, by the mid 196os, internal politics in Indonesia had become a matter of conflict between cliques and regions rather than between clearly defined socioeconomic classes. ${ }^{6}$ The leadership of the Communist Party tended to criticize

4 Wertheim did not attempt to quantify the middle class. It must have been small, whatever definition was used. Most civil servants were in the lower grades and most of those in state enterprises would have been working in at best semi-skilled occupations, with low salaries. The 1961 census showed that only $3 \%$ of the population over 10 had completed more than primary education (Nugroho 1967:143).

5 Van Der Kroef (1963) gives a detailed discussion of the evolution of the Indonesian Communist Party's thinking on agrarian reform issues, both before and after 1945. He argues that the post-independence PKI was cautious in its approach to land reform and reluctant to cause problems for the Sukarno regime, especially after 1960.

6 Mortimer (1982:60-1) also argued that in the 1950s, 'in the absence of strong class pressures, political parties and mass organizations organized their followings largely along lines of 
bureaucratic capitalists who appropriated the surplus created by state enterprises at the expense of workers. As Castles pointed out, many commentators in the press and elsewhere saw the leadership of the state enterprises, created after the nationalizations of the late 1950s, as inefficient and corrupt, enjoying high living standards at a time when many workers in both the state and private sectors faced declining real incomes. It was often the newly qualified graduates, unable to access the more lucrative jobs in the state sector, who were most critical of the окв (orang kaya baru, the new rich) and who were often the most vocal critics of the Sukarno regime after the failed coup in 1965 . The great majority of university graduates came from the upper-income groups and reflected the frustrations of those families who had invested in their children's education but in a stagnant economy found they were barred from well-paying jobs in either the public or the private sector.

In the mid 196os, data from household surveys became available for both Java and some provinces outside of Java. They showed, using a poverty line based on rice prices, that a large proportion of the population on Java was either very poor or poor ( $80 \%$ in 1967 ), while only $5.4 \%$ could be considered self-sufficient. Outside Java, the proportions deemed very poor or poor were somewhat lower, but in $1964 / 65$ only $10 \%$ were self-sufficient. On both Java and the outer islands, the number of people classed as very poor fell quite sharply as a percentage of the total after $1969 / 70$, but in 1984 the self-sufficient still formed less than a quarter of the total population on Java, although closer to half outside of Java (Booth 1988:193). On Java, in the mid 196os, it appears that the population could be divided into a poverty-stricken mass and a small percentage enjoying an income that allowed the purchase of some consumer durables. The fortunate minority were likely to have been senior civil servants who could make money from selling import and other licences; employees in estate enterprises who could participate in smuggling their output to neighbouring Malaysia; and a small number of indigenous and Chinese businessmen. The better-off farmers who were cultivating land holdings of around one hectare or more, including some irrigated land, and who had surplus produce which could be sold on local markets, were also likely to be self-sufficient or even moderately

religious and cultural cleavage'. After 1960, in return for a measure of protection and freedom to organize at the grass roots level, the PKI moderated their specifically class-based appeal and followed the more inclusive rhetoric of Sukarno. But at the same time, PKI cadres did carry out participatory action research, mainly on Java in the early 196os; White (2016) gives an overview of their work. Farid (2005:176-7) argued that the writings of Aidit and other senior party figures on rural class formation copied the writings of Mao in particular. 
affluent. But the great majority of the rural population was still poor, even using a modest poverty line.

The situation outside Java was different because agricultural holdings on average were somewhat larger and, during the course of the 196os, most of the export-producing regions were trading directly with ports in Malaysia and Singapore, receiving higher prices than if they had used legitimate channels and the official exchange rate. ${ }^{7}$ The class of farmers producing for national and international markets was probably larger than on Java. These better-off farmers might have had some influence in local politics, but they do not appear to have had much influence at the national level. The rural poor, especially on Java and Bali, were attracted to the Communist Party and its farmer organizations because they promised land reform. But as Wertheim (1956:279) argued, class divisions and class solidarity in Indonesia in the early post-independence years were often 'cut across by considerations of ideology, tradition, economics and by chance considerations having to do with the veneration in which certain personalities are held'. This continued to be the case until the Communist Party was eliminated in 1965/66 and other political parties were co-opted by the New Order state.

The group of technocrats which Soeharto assembled around him in 1966 gave top priority to reducing inflation, unifying the exchange rate and bringing it into line with the rates on international markets, and bringing order to the public finances. By 1969, these goals had been met, at least to the point where the government felt confident to embark on the first of six five-year plans initiated between 1969 and 1994. Numbers in extreme poverty were declining. In rural Java, the proportion of the population considered very poor fell from $67 \%$ in 1967 to $51 \%$ in $1969 / 70$. But most of these probably only improved their incomes to a modest extent, as the proportion of the population in the poor groups increased (Booth 1988:193). Outside Java, there was a steep fall in the percentage of people classed as very poor and a smaller drop in the numbers of people classed as poor between 1964/65 and 1969/70 with rises in the percentage of people considered almost self-sufficient and self-sufficient. It is probable that many households outside Java producing for both domestic and international

7 The benefits from smuggling did not always accrue to producers. Castles (1965:37-8) found that in some parts of Sumatra, army-backed traders forced rubber exporters to sell to them at low prices and then sold the rubber in Singapore at much higher prices. 
markets benefited from both the stabilization of domestic prices and the more realistic exchange rate.

But these changes probably had little immediate impact on class structures. A breakdown of all employed persons in urban areas by monthly earnings showed that those in the private sector (around $10.4 \%$ of the total) who were employed in professional, technical, administrative, and clerical occupations earned considerably more than government employees (who comprised almost $15 \%$ of the total). It would appear that already in the early New Order era, those in secure jobs in the private sector were earning more than government employees (Booth and Sundrum 1981: Table 7.14). This inevitably influenced the job choices made by well-qualified young people coming out of the education system in the 1970s and beyond, including those from high-status priyayi families with a tradition of government employment (Lev 1990:29).

Economic growth was rapid from 1968 to 1981, fuelled not just by the oil boom but also by inflows of both aid and foreign investment into the petroleum sector and manufacturing. Government expenditures through the annual budgets rose as a percentage of GDP, which itself was growing at over $7 \%$ per annum. The food crop sector was assisted by generous government subsidies for both fertilizer and irrigation, which facilitated the adoption of new, higheryielding varieties of rice and corn. But in spite of the growing prosperity of the class of farmers cultivating relatively large amounts of land, those studying the emergence of the middle class in Indonesia in the early part of the Soeharto era tended to see it as an urban phenomenon, based on changing consumption standards in Jakarta and other large cities (Dick 1985). Although some employees in the private sector were earning high salaries relative to government employees, the urban cost of living surveys carried out in 1977/78 showed that family incomes in households where the head was in government service grew relative to the average in all the large cities in Indonesia (Booth 1992: Table 10.10). Civil service remuneration increased over the 1970s, partly as a result of higher basic salaries but also because many government workers received supplementary allowances of various kinds, depending on their access to work on projects funded from the development budget (Gray 1979). Such supplements were often justified on the grounds that higher salaries were needed to attract and retain graduates in disciplines such as engineering who might otherwise have gone to the private sector.

Although Dick (1985:75) argued that it was too simple to view the growth of the middle class exclusively in terms of growing incomes and expenditures on assets including housing and consumer durables, several studies of social stratification in the 1970s and 1980s did rely mainly on income and expenditure data collected by the Biro Pusat Statsitik (Central Bureau of Statistics). 
Dick cited the work by Downey (1983), which showed ownership of consumer durables by employment groups; he estimated the percentage of individuals with access to cars, motorcycles, refrigerators, televisions, and stereos by employment groups. Self-employed professionals, managers, and other professionals tended to have greater access to these goods than manual workers and other self-employed. Downey's work encouraged the Central Bureau of Statistics to construct a series of social-accounting matrices, beginning in $19755^{8}$ These showed average incomes by social group in both urban and rural areas (Table 1). The group which was clearly 'middle class', in the sense that Dick used the term, was the upper-income group in urban areas; in 1975 they comprised only around $6 \%$ of the total population but accounted for $20 \%$ of disposable incomes. The largest group in terms of population were farmers operating holdings of less than half a hectare; they comprised $22 \%$ of the population but only received $12.3 \%$ of total disposable income. It is unlikely that many of them considered themselves middle class, by any definition.

By 1985 , the top group in urban areas had increased to $8.4 \%$ of the population, but their share of total income had declined to $18 \%$, although this was still a larger share of total disposable income than any other group (Table1). The social-accounting matrices (SAM) did not give breakdowns of the 10 categories according to type of employment; for example, the category 'top group in urban areas' must have comprised both public and private sector employees, but the exact numbers are not given. The decline in the share of income accruing to the top urban group between 1975 and 1985 was in part a consequence of the slower growth in public service salaries and perquisites after the oil boom ended in the early 1980s. The slower economic growth between 1981 and 1985 compared with the oil boom years must have affected remuneration in the private sector as well. Between 1985 and 1995, economic growth accelerated, with rapid growth in manufacturing, construction, and the modern service sector. Over this decade, the income shares of both the lower and upper groups in urban areas increased, while the income share of the agricultural sector fell (Table 1).

Over the 1980s, there was more discussion of the growth of the middle class in Indonesia, much of it by political scientists. Lev (1990:26) suggested that a key reason why Indonesian scholars were interested in the kelas menengah baru (new middle class) was that it was seen as an agent of change in a society that was both experiencing rapid economic growth after decades of stagnation and in which the government was determined to control the emergence of new political movements. How big was this new class? Mackie (1990:98-9) argued that the middle class in Indonesia, although growing in numbers, was

8 These continued to be compiled and published until 2008. 
TABLE 1 Distribution of population and disposable income by socio-economic group, 1975, 1985, and 1995

$\begin{array}{llll}\text { Socio-economic group } & 1975 & 1985 & 1995\end{array}$

\% Pop. \% Income \% Pop. \% Income \% Pop. \% Income

Rural:

$\begin{array}{lrrrrrr}\text { Farm labourers } & 11.7 & 6.0 & 7.0 & 4.1 & 10.7 & 3.2 \\ \text { Small farmers } & 22.2 & 12.3 & 23.8 & 13.2 & 16.9 & 7.8 \\ \text { Medium farmers } & 12.0 & 8.8 & 8.0 & 6.6 & 7.1 & 4.2 \\ \text { Large farmers } & 13.7 & 14.9 & 9.7 & 12.9 & 5.5 & 4.7 \\ \text { All farmers } & 59.6 & 42.0 & 48.5 & 36.8 & 40.2 & 19.9 \\ & & & & & & \\ \text { Non-farm: lower } & 14.7 & 10.0 & 13.4 & 9.8 & 14.7 & 12.8 \\ \text { Not working } & 3.0 & 2.7 & 5.1 & 3.6 & 4.7 & 3.9 \\ \text { Non-farm: upper } & 6.0 & 11.6 & 8.2 & 10.3 & 7.8 & 13.2 \\ \text { All non-farm } & \mathbf{2 3 . 7} & \mathbf{2 4 . 3} & \mathbf{2 6 . 7} & \mathbf{2 3 . 7} & \mathbf{2 7 . 2} & \mathbf{2 9 . 9}\end{array}$

Urban:

\begin{tabular}{lrrrrrr} 
Lower groups & 9.2 & 11.5 & 12.6 & 16.5 & 17.4 & 19.4 \\
Not working & 1.5 & 2.1 & 3.8 & 5.0 & 5.2 & 5.3 \\
Upper groups & 6.1 & 20.2 & 8.4 & 18.1 & 9.6 & 25.5 \\
All Urban & $\mathbf{1 6 . 8}$ & $\mathbf{3 3 . 8}$ & $\mathbf{2 4 . 8}$ & $\mathbf{3 9 . 6}$ & $\mathbf{3 2 . 2}$ & $\mathbf{5 0 . 2}$ \\
\hline
\end{tabular}

Note: Small farmers are those households owning less than 0.5 hectares, medium farmers are those owning between 0.5 and one hectare, and large farmers are those owning more than one hectare. For definitions of lower and upper non-farm and urban households, see the source document.

SOURCE: BADAN PUSAT STATISTIK (2OO8), TABLES 3.31 AND 3.32

smaller and weaker than in other non-communist societies in East and Southeast Asia. He quoted estimates that less than $5 \%$ of the population belonged to well-off urban classes, although he admitted that there would have been some rural households with comparable incomes and wealth. He also pointed out that a significant proportion would probably have been Chinese, although he admitted that quantification was impossible, given that no statistics were broken down by ethnicity. ${ }^{9}$

9 I attempted to estimate the proportion of the urban and rural populations living above an 
The evidence of a growing class of relatively affluent people in urban areas, especially on Java, was accompanied by evidence that inequalities in urban areas were increasing. Although the Indonesian government has never published estimates of relative poverty, the data from the social surveys (Survei Sosial Ekonomi Nasional, Susenas) showed a jump in the proportion of the urban population earning less than half the average per capita consumption expenditure between 1987 and 1996 (from $18.1 \%$ to $23.2 \%$ ). The increase was especially pronounced in Jakarta and urban West Java (Booth 2000: Table 10). This increase did not imply that the lower-expenditure groups in urban areas were poorer in absolute terms but rather that an increasing proportion of the population was spending less than half the average per capita expenditure. In this sense the gap between expenditure classes in urban areas was widening.

In rural areas, the evidence showed some increase in relative poverty between 1987 and 1996, although this was much smaller than the growth in relative poverty in urban areas. Over the two decades from 1975 to 1995, the share of the farming population in the total population fell from almost $60 \%$ to $40 \%$, and their share of total disposable income fell from $42 \%$ to $20 \%$ (Table 1 ). All categories of agricultural household saw their disposable incomes fall compared with urban groups between 1975 and 1995, although large farmers did better than other groups (Table 2).$^{10}$ How many households in rural areas would have considered themselves middle class, or even modestly well-off, by 1995 is open to debate, but it must have been less than the percentage in urban areas. As mobility increased, and as more rural people were exposed to urban areas and urban lifestyles, it is likely that they became more conscious of the disparities, not just in incomes but also in access to education, health care, and other services.

That the government was becoming more aware of public concern over equity issues over the 1980 os and 199os is clear from presidential and ministerial statements and from the five-year-plan documents (Rencana Pembangunan Lima Tahun, Repelita). The third five-year plan, which ran from 1979 to

'affluence line' in the 1970s and 1980s; there was a sharp increase in the proportion living in urban Java between $1969 / 70$ and 1987 , from $18.7 \%$ to $47.6 \%$. There was only a slight increase in the proportion in urban areas outside Java, a slight fall in rural Java, and a very steep fall in rural areas outside Java (Booth 1992: Table 10.20). It is likely that by 1987 , the affluence line I used was too low to provide a middle-class lifestyle, but the estimates do suggest that over these two decades, consumption by households in urban Java were forging ahead relative to other parts of the country.

10 The evidence that incomes of large farmers grew faster than small farmers and the landless supports those who argued that within rural areas, gaps between rich and poor increased over the decades from 1975 to 1995. Pincus (1996) summarizes this literature. 
TABLE 2 Growth of disposable incomes relative to poorest class (farm labourers) 19752005

\begin{tabular}{lcccc}
\hline Socio-economic group & 1975 & 1985 & 1995 & 2005 \\
\hline Rural & & & & \\
Farm labourers* & 100 & 100 & 100 & 100 \\
& $(39 \cdot 93)$ & $(239 \cdot 94)$ & $(616.69)$ & $(4359 \cdot 17)$ \\
Small farmers & 108 & 95 & 152 & 114 \\
Medium farmers & 143 & 142 & 195 & 174 \\
Large farmers & 207 & 223 & 285 & 240 \\
Non-farm: lower & 132 & 127 & 286 & 188 \\
Not working & 177 & 120 & 279 & 207 \\
Non-farm: upper & 373 & 218 & 556 & 350 \\
& & & & \\
Urban & & & & 240 \\
Urban: lower & 237 & 225 & 369 & 248 \\
Not working & 277 & 226 & 337 & 496 \\
Urban: upper & 620 & 370 & 846 & 216 \\
Average: all groups* & 192 & 172 & 331 & $(9392.66)$ \\
& $(76.59)$ & $(413.53)$ & $(2038.76)$ & \\
\hline
\end{tabular}

*Figures in brackets refer to disposable income per capita (Rp ‘ooo, nominal). In all years shown, farm labourer households had the lowest disposable incomes per capita.

Note: Small farmers are those households owning less than 0.5 hectares, medium farmers are those owning between 0.5 and one hectare, and large farmers are those owning more than one hectare. For definitions of lower and upper non-farm and urban households, see the source document.

SOURCE: BADAN PUSAT STATISTIK (2OO8), TABLES 3.29 AND 3.30

1984, stressed eight paths to equality, including not just a fair distribution of income but also greater equality in access to education, health, and infrastructure (Dick 1985:89-90). The sixth five-year plan, which was scheduled to run from 1994 to 1999, was the first to contain a chapter devoted to 'shared development and poverty alleviation'. The chapter gave prominence to Indonesia's success in reducing poverty between 1969 and 1994 and expressed the hope that by the end of the seventh plan (1999-2004) further economic growth, together with specific government initiatives, would reduce numbers below the official poverty line to zero (Booth 1994:36). These poverty estimates and predictions were treated with some scepticism at the time. Many considered 
that the poverty line used was too low and could not fund an adequate basket of basic needs at the prices prevailing in the early 199os. Certainly from the mid 1980s onwards, the poverty line had fallen relative to average per capita consumption expenditures, especially in urban areas (Booth 2000: Table 4).

Political scientists seeking to explain changes in power structures in Indonesia in the Soeharto era have tended to do so in terms of 'centralized clientelism', and the strengthening of the bureaucratic polity (Aspinall and Berenschot 2019:51). It was argued that the political parties that were powerful in the early post-independence era were banned or obliterated (Masjumi and the PKI) or consigned to a minor role in the heavily managed elections that took place in after 1971. McVey (1982) argued that the political system established by Soeharto in effect re-established the colonial beamtenstaat, where the real political decisions took place within the bureaucracy itself and other institutions played only a marginal role. An implication of these arguments was that, to the extent that a middle class was emerging in Indonesia after 1965, it comprised government officials and those private sector businesspeople who depended on government contracts and other favours in order to grow their businesses. The continuing role of the Chinese in the private sector was also acknowledged, albeit difficult to quantify.11

But some commentators were criticizing the argument that the Soeharto state, dominated by a powerful official class, was stifling the growth of private enterprise, except for a small number of large conglomerates dominated by Chinese with close links to Soeharto and his family. By the 199os, many bright, young people with degrees from the best universities were gravitating to the private sector, not just because salaries were higher but because promotion was perceived to be based on merit and there was less pressure to be involved in corrupt practices. By the early 199os, official documents were stressing the greater reliance on the private sector as a source of investment funds. The sixth plan document reported that by 1993/94, $73 \%$ of total investment originated from private sources (domestic and foreign). This was a much higher proportion than a decade earlier (Booth 1994:10). The sixth plan forecast that $73.4 \%$ of investment would originate from domestic sources over the five years until $1998 / 99$, and only $6 \%$ of investment funds would come from foreign sources,

11 Following Robison (1986), there were a number of studies of conglomerates, defined as large business groups often involved in a number of different sectors. Most of the largest ones were owned either by members of the Soeharto family or businessmen of Chinese descent who had close links to Soeharto and other key politicians. Habir (1999) gives a good summary of the role of large conglomerates over the 1990 . 
either through government borrowing or private investment inflows. But the fall of Soeharto meant that this plan was never completed.

\section{The Post-Soeharto Era}

The economic crisis that erupted in Asia with the Thai government's decision to float the baht in July 1997 had a serious economic impact in Indonesia. Real GDP fell by over 13\% in 1998 and recovered slowly; it only returned to the 1997 figure in 2004. Real per capita GDP growth in the decade from 1995 to 2005 was only $1.2 \%$ per annum, a much lower rate than between 1965 and $1995 \cdot{ }^{12}$ It has been asserted that the economic crisis had a more serious impact on urban areas than on rural areas, and within urban areas the upper-income groups suffered a larger income decline than the poorer groups. The social-accounting matrices published after 1995 lend some support to these arguments. Between 1995 and 2005, the disposable incomes of the ten income groups in the SAM fell relative to the poorest group (agricultural-labourer households). The four categories of agricultural households (labourers, small, medium, and large farmers) increased their share of total disposable income between 1995 and 2005, while the share of urban dwellers fell (Table 3 ). The average disposable incomes of the richest urban category as a proportion of total income fell from $25 \%$ to $20.3 \%$. The improvement in the position of agricultural households, including labourers, relative to households in urban areas, between 1995 and 2005 can be explained by the impact of the crisis. In rural areas, farmers producing export crops benefited from an increase in rupiah prices, although domestic inflation eroded some of the gains. In urban areas many people either lost their employment entirely (for example, in the construction sector) or, in the case of many enterprises in manufacturing, trade, transport, and other services, faced falling demand as most households reduced expenditures on nonessential items.

In 2004, the Indonesian economy had recovered to the 1997 level of per capita GDP, and Susilo Bambang Yudhoyono became the first president elected by popular vote. Growth rates between 2004 and 2010 were solid, and the economy was less affected by the global downturn in 2007/8 than its neighbours. The proportion of the population below a poverty line of US $\$ 1.25$ (adjusted for purchasing-power parities) fell between 1999 and 2009, while that in the expenditure groups above US\$2 a day rose. ${ }^{13}$ In a paper published in 2010,

\footnotetext{
12 These estimates are based on Van der Eng 2013.

13 An extended discussion of the purchasing-power parity data is given in World Bank 2020.
} 
TABLE 3 Distribution of population and disposable income by socio-economic group, 1995, 2000 , and 2005

$\begin{array}{llll}\text { Socio-economic group } & 1995 & 2000 & 2005\end{array}$

\% Pop. \% Income \% Pop. \% Income \% Pop. \% Income

Rural:

$\begin{array}{lrrrrrr}\text { Farm labourers } & 10.7 & 3.2 & 15.2 & 7.3 & 13.5 & 6.3 \\ \text { Small farmers } & 16.9 & 7.8 & 18.9 & 10.4 & 17.7 & 9.4 \\ \text { Medium farmers } & 7.1 & 4.2 & 6.4 & 5.2 & 6.6 & 5.3 \\ \text { Large farmers } & 5.5 & 4.7 & 4.8 & 5.6 & 4.6 & 5.1 \\ \text { All farmers } & 40.2 & \mathbf{1 9 . 9} & \mathbf{4 5 . 3} & \mathbf{2 8 . 5} & \mathbf{4 2 . 4} & \mathbf{2 6 . 1} \\ & & & & & & \\ \text { Non-farm: lower } & 14.7 & 12.8 & 14.6 & 11.6 & 15.8 & 13.8 \\ \text { Not working } & 4.7 & 3.9 & 5.1 & 5.4 & 4.8 & 4.6 \\ \text { Non-farm: upper } & 7.8 & 13.2 & 6.5 & 10.5 & 6.9 & 11.2 \\ \text { All non-farm } & \mathbf{2 7 . 2} & \mathbf{2 9 . 9} & \mathbf{2 6 . 2} & \mathbf{2 7 . 5} & \mathbf{2 7 . 5} & \mathbf{2 9 . 6}\end{array}$

Urban:

$\begin{array}{lrrrrrr}\text { Lower groups } & 17.4 & 19.4 & 14.8 & 18.0 & 16.0 & 17.8 \\ \text { Not working } & 5.2 & 5.3 & 5.1 & 7.7 & 5.4 & 6.2 \\ \text { Upper groups } & 9.6 & 25.5 & 8.5 & 18.5 & 8.8 & 20.3 \\ \text { All Urban } & \mathbf{3 2 . 2} & \mathbf{5 0 . 2} & \mathbf{2 8 . 4} & \mathbf{4 4 . 2} & \mathbf{3} \text {-.2 } & \mathbf{4 4 . 3}\end{array}$

Note: Small farmers are those households owning less than 0.5 hectares, medium farmers are those owning between 0.5 and one hectare, and large farmers are those owning more than one hectare. For definitions of lower and upper non-farm and urban households, see the source document.

SOURCE: BADAN PUSAT STATISTIK (2OO8), TABLES 3.31 AND 3.32

the Asian Development Bank argued that the proportion of the population in Indonesia that could be classified as middle class had risen between 1999 and 2009 from $25 \%$ of the population to $43 \%$, using a definition of middle class as spending between US $\$ 2$ and US $\$ 20$ per day. It was acknowledged that this definition was rather arbitrary and that 'there was no single universally

The World Bank carried out an estimation of purchasing-power parities in 2005, 2011, and 2017. They attempt to allow for the fact that national income data converted into dollars at prevailing exchange rates do not fully compensate for differences in prices of goods and services across countries. 
TABLE 4 Percentage distribution of the population by per capita daily expenditure group: Indonesia 1999 and 2009 and the Philippines 2006

\section{Indonesia Indonesia Philippines \\ $19992009 \quad 2006$}

\section{Expenditure groups (2005 PPPUS\$)}

\begin{tabular}{|c|c|c|c|}
\hline Under US\$1.25 & 42.2 & 24.6 & 21.8 \\
\hline US\$1.25 to US\$2.0o & $3^{2.8}$ & 32.4 & $23 \cdot 7$ \\
\hline US\$2.0o to US\$ 4.00 & 20.1 & 30.9 & 30.7 \\
\hline US\$ 4.00 to US\$6.0o & $3 \cdot 5$ & $7 \cdot 5$ & 11.8 \\
\hline US\$ 6.oo to US\$10.0o & 1.2 & $3 \cdot 3$ & 8.1 \\
\hline US\$10.0o to US\$20.00 & 0.3 & 1.1 & $3 \cdot 4$ \\
\hline Over US\$20.0o & 0.0 & 0.2 & o.6 \\
\hline Total US\$ 4 to US\$2O & $5 \cdot 0$ & 11.9 & $23 \cdot 3$ \\
\hline Urban US\$ 4 to US\$2O & 11.0 & 21.9 & $37 \cdot 3$ \\
\hline Rural US\$ 4 to US\$ 20 & 1.1 & 4.5 & $9 \cdot 4$ \\
\hline
\end{tabular}

SOURCE: ASIAN DEVELOPMENT BANK (2O10), TABLES 2.7, 2.8

accepted definition' of what constitutes a middle class (Asian Development Bank 2010:13). Given that many people spending between US\$2 and US $\$ 4$ per day were still likely to be insecure and vulnerable to a decline in income and expenditure that could push them back into poverty, a better definition of middle class would probably be those spending at least US $\$ 4$ per day. Those spending more than twenty dollars a day could be considered rich. Using the four-to-twenty-dollar range, the proportion of the population that could be called middle class in Indonesia had risen to $11.9 \%$ in 2009 compared with $5 \%$ in 1999 (Table 4).

The Asian Development Bank (ADB) argued that, in all the Asian countries that they investigated, the middle class, defined in terms of expenditures corrected for purchasing-power parities, was mainly concentrated in urban areas and employed in salaried jobs. Not many could be classified as self-employed entrepreneurs, or 'capitalists in waiting'. The middle class tended to be better educated than the poorer groups in the population; their fertility rate was lower and their family size smaller. Of those who self-identified as middle class in surveys, Indonesia stood out as having a rather low proportion in gov- 
ernment employment. In Vietnam, $74.4 \%$ of the self-identified middle class were employed in government and parastatal enterprises; in China, $45.9 \%$. In Indonesia it was only $32.3 \%$, compared with $64.3 \%$ in private business and industry (Asian Development Bank 2010: Figure 3.3).

The ADB estimates showed that in 2009 the proportion of the population in the four-to-twenty-dollar range was somewhat smaller in Indonesia than in the Philippines in 2006, in spite of the Philippines having a lower per capita GDP. While the proportion of the population in the two countries in the two-to-four-dollar range was much the same, there was a higher proportion of the population in Indonesia in the under-two-dollar groups (Table 4). In other words, a higher proportion of Indonesians were either poor or very poor: $57 \%$ of Indonesians in 2009 compared with only $45.5 \%$ of Filipinos in 2006. Does this indicate a consistent understatement of household expenditures in Indonesia, compared with the Philippines? The ADB did acknowledge problems in the survey data, not just in Indonesia and the Philippines but also in other Asian countries, including China. In both the Philippines and Indonesia, a large disparity had emerged in both countries between the household survey data and the national income estimates by the early years of the twenty-first century, although the ADB report did not fully explore the consequences of this problem for their estimates.

A further analysis of the size of the middle class in Indonesia, also using household expenditure data from the Susenas surveys, was published in 2019 by the World Bank. ${ }^{14}$ This report divided the Indonesian population in both urban and rural areas into five groups: the poor, the vulnerable, the aspiring middle classes, the middle class, and an upper class of rich people. Monthly consumption expenditure data in rupiah were used to establish cut-off points for each class; the rupiah data were converted into dollars, adjusted for purchasing power, using the 2016 Purchasing Power Parity or PPP estimates. A breakdown of population numbers in four categories (excluding the top group) was given for 2002 and 2016. As would be expected, given the economic growth that occurred over these fourteen years, numbers in poverty and in the vulnerable category fell, while those in the aspirational middle class and the middle class grew in both urban and rural areas (Table 5). In 2016, 53.6 million people were considered middle class using the definitions given in Table 5 , compared with only 13.8 million in 2002 .

The cut-off expenditure for the poor was an average of the urban and rural poverty lines used by the Badan Pusat Statistik (now also using the English

14 This study also provides a useful summary of definitions of the middle class used in previous studies. See World Bank 2019, Table A1.1. 
TABLE 5 Indonesian population by social categories, 2002 and 2016 (millions)

\begin{tabular}{lcccc} 
Category & \multicolumn{2}{c}{2002} & \multicolumn{2}{c}{2016} \\
& Urban & Rural & Urban & Rural \\
& & & & \\
\hline Middle class & 10.3 & 3.5 & 40.6 & 13.0 \\
Aspirational & 41.1 & 42.3 & 54.2 & 60.5 \\
Vulnerable & 25.3 & 4.3 & 27.5 & 34.1 \\
Poor & 13.0 & 23.7 & 10.3 & 17.7 \\
\end{tabular}

Note: The poor are defined as those with monthly per capita expenditures below Rp. 354,00o per month (US\$2.20 in 2016 PPP adjusted terms). The vulnerable are those with monthly per capita expenditures between Rp. 354,000 and Rp. 532,000 (US\$2.20 to US\$3.30 in 2016 PPP prices). The aspirational middle classes are those with monthly per capita expenditures between Rp. 532,0oo and Rp. 1.2 million. This group is considered to have a $10 \%$ chance of falling back to the vulnerable group. The middle class are those with monthly per capita household expenditures between Rp 1.2 million and Rp. 6 million. Those with expenditures above $\mathrm{Rp} 6$ million per month are considered rich. For more discussion of the PPP data, see World Bank (2020).

SOURCE: WORLD BANK (2O19), FIGURE 3.2

name Statistics Indonesia). The vulnerable were the group spending between Rp 354,000 and Rp 532,00o per capita per month; they were considered to be above the poverty line but still vulnerable to income declines that could push them back into serious poverty. The aspiring middle classes were spending between Rp 532,00o to Rp 1.2 million per month; this group was considered to have a $10 \%$ chance of falling back into the vulnerable group. The middle class was spending between $\mathrm{Rp} 1.2$ and Rp 6 million (US\$7.75 to US\$30 dollars)..$^{15}$ This group was considered economically secure and affluent enough to purchase a range of more expensive consumer durables and services (cars, air conditioners, computers, internet access, et cetera). The middle class was also on average better educated than the other groups, with the great majority having completed high school and many holding tertiary qualifications. Around $76 \%$ were living in urban areas, and many of those were in the larger conurbations on Java, with 13 million in the Greater Jakarta area. Most were in formal sector employment, and over half were working as employees. ${ }^{16}$

\footnotetext{
15 The adjustment into dollars was made using purchasing-power parity data from the 2017 study carried out by the World Bank. For more details, see World Bank 2020.

16 Similar results have been found for the Philippines, where a high proportion of the
} 
In spite of the higher expenditures of the middle classes compared with the rest of the population, the World Bank report pointed out that half of those in the middle class were still deprived on at least one non-monetary dimension, often because of poor-quality housing and inadequate sanitation (World Bank 2019:37-8). Even in the more prosperous neighbourhoods of cities such as Jakarta and Surabaya, their homes were often vulnerable to flooding in the rainy season, and along with the rest of the population they suffered from poor air quality, traffic congestion, and pollution of water sources. ${ }^{17}$ The report also argued that even the most affluent groups remained vulnerable to shocks such as illness or death of a family member, especially the main earner. Although the government introduced a universal social insurance scheme in 2014 (Sistem Jaminan Sosial Nasional), it does not cover all risks and the benefits are often small relative to loss of earnings. Middle-class families are increasingly buying into private-insurance schemes, which cover private medical treatment as well as life insurance. In addition, increasing numbers of middle-class Indonesians are unsatisfied with the quality of public education and send their children to private schools (World Bank 2019:39-42).

The increasing use of private facilities for health and education by the upperincome groups in Indonesia raises complex questions about social mobility and the life chances of children, not just in households classified as poor or vulnerable but also in those who aspire to middle class status. If the pathway to well-paid and secure jobs is via private schools and elite universities in Indonesia or abroad, it may be that in future young people from less privileged backgrounds will find their way to more secure employment blocked. It is striking that, over the last two decades, there has been a very rapid growth in the employed labour force with post-secondary qualifications. Between 1996, the last normal year before the Asian financial crisis hit, and 2019, the last normal year before the pandemic hit, numbers of employed workers in Indonesia grew by $50 \%$ for males and $52 \%$ for females. But the growth in employed workers with post-secondary qualifications (diplomas and degrees) was much more rapid, especially for women (Table 6). It appears that after the crisis, many parents decided that investment in post-secondary education was vital in order to improve their children's life chances.

upper middle class is concentrated in Metro Manila and its immediate surroundings, and employed in mainly salaried occupations (Albert, Santos and Vizmanos 2018).

17 Many people in urban Indonesia, not just those in the upper-income groups, now use bottled water rather than polluted tap water, which even after boiling tastes unpleasant. The large numbers of discarded plastic bottles have added to problems of pollution in rivers and canals. 
TABLE 6 Growth in the employed labour force by gender (1996-2019) and breakdown by sectors and educational qualifications, 2019

Male

Female

Growth in employed labour force $(1996=100)^{*}$

Total employed workers

150

$15^{2}$

Workers with diplomas

164

354

Workers with university degrees

619

1325

Percentage of total employed labour force by sector, 2019:

Government administration and defence

Educational services

3.1

Health and social services

0.8

2.7

All government-related services

8.4

13.4

Percentage of employed labour force in government-related services by qualification:

Employed workers with diplomas

$27 \cdot 7$

$54 \cdot 5$

Employed workers with degrees

$45 \cdot 9$

66.7

\footnotetext{
* 1996 data adjusted to remove workers under 15

SOURCES: 1996 DATA: CENTRAL BUREAU OF STATistics (1997), PP. 35-6. 2019 DATA:

CENTRAL BOARD OF STATISTICS (2O19), TABLES 11.1 TO 11.5
}

How many of those in the labour force in 2019 with tertiary qualifications would be middle class according to the definition used by the World Bank? This is not an easy question to answer, as the data from the labour force surveys refer to individuals, not households, and it is likely that many households with incomes above the middle-class threshold have two earners with postsecondary qualifications. Although female labour force participation rates in Indonesia are on average only about $52 \%$, which is lower than in Thailand or Vietnam, for women with post-secondary qualifications they are much higher (Table 7). Many women with post-secondary qualifications in $2019(67 \%$ of those with university degrees) were employed in government administration or in the education and health sectors, where many would also be in government employment. To the extent that they were living in households where at least one other member had similar qualifications and were in similar occupations, it is likely that the income of the household would be close to or above the middle-class threshold. What determines a 'middle-class' income and lifestyle may not be whether the main earner is in the public or private sector but rather how many incomes are coming into the household from any source. 
TABLE 7 Labour force participation rates by gender and educational qualification, 2019

\begin{tabular}{lclll}
\hline & Total & $\begin{array}{l}\text { University } \\
\text { degree }\end{array}$ & Diploma & $\begin{array}{l}\text { Vocational } \\
\text { high school }\end{array}$ \\
\hline Male & 83.1 & 92.2 & 87.9 & 90.0 \\
Female & 51.9 & 80.7 & 68.7 & 60.7 \\
Total & 67.5 & 86.4 & 76.4 & 78.2 \\
\hline
\end{tabular}

SOURCE: CENTRAL BOARD OF STATISTICS (2O19), TABLES 2.01 TO 2.05

These questions merit further research, as does the regional distribution of those in both government and private sector employment. In their discussion of an index that reflects perceptions of clientelism in different parts of Indonesia, Aspinall and Berenschot (2019:244-8) find that the index is low in Jakarta and West, East, and Central Java, where the economy is more diversified, and where many rural households now derive more than half their income from off-farm sources. ${ }^{18}$ But in many parts of Sumatra, Kalimantan, Sulawesi, and Eastern Indonesia, opportunities to make money without having recourse to the government sector, and therefore to corrupt practices, are limited. This in turn may make the middle classes in the urban areas outside Java more tolerant of, and complicit in, corrupt practices as they have often benefited from them and expect to do so in the future. In the provinces of Java, there are far more employment opportunities in the private sector, at least for well-educated urban dwellers.

It has been claimed, especially by social scientists who argue that oligarchic power structures are still entrenched in post-Soeharto Indonesia, that 'the growing middle classes are typically directly or indirectly dependent on the state and lack the will and/or capacity to challenge oligarchic power' (Rodan and Baker 2020:88). However, these authors do not provide much evidence to support these assertions. In fact, it appears that budgetary revenues and expenditures have been falling relative to GDP since the 1980s; recent OECD data show that the tax/GDP ratio in Indonesia is now low in comparison with

18 A study of five villages on the north coast of Central Java found that the proportion of middle-class households increased from 6\% in 1990 to $27 \%$ in 2012 (Wicaksono 2020). In 1990, most households defined as middle class were landowners who benefited from government subsidies; by 2012, some households had become middle class through establishing successful small enterprises, which they built up using money from wage labour. 
other Asian countries (Carroll 2020: Table 2.4). These indicators suggest that the Indonesian fiscal state has grown weaker over the past three decades and created more space for an independent private sector. ${ }^{19}$

Another important trend concerns the role of the Chinese in the growth of the middle class. The 2010 census reported that only 2.8 million gave their ethnicity as Chinese, which was a little more than $1 \%$ of the population (Booth 2016:146). Even if there was under-reporting and the true number was higher, at perhaps four million, it seems that at most $10 \%$ of the middle class as defined by the World Bank was of Chinese ethnicity. The true percentage was probably less, because not all Chinese households would have reached the middle-income threshold defined by the World Bank. ${ }^{20}$ Whereas in the late colonial and early post-independence periods it was widely assumed that the top-income earners in the private sector would have been disproportionately Chinese, this was much less the case by 2016 .

For almost a century, academics have analysed the determinants of class formation in Indonesia. Until the 1980s, the majority of the population was living in rural areas, and land ownership was viewed as an important determinant of incomes and of social status. As more Indonesians gained some education and access to salaried employment in both the public and the private sectors in the final decades of Dutch colonial rule, scholars such as Kahin and Wertheim examined the consequences of access to non-agricultural employment for class formation. After 1950, salaried employment opportunities in both the public and the private sectors for indigenous Indonesians expanded, although in the decade from 1958 to 1968 economic stagnation and mounting inflation eroded the incomes of those in salaried employment and created few new opportunities for young people entering the workforce in non-agricultural employment.

19 Numbers of permanent civil servants (PNS) have actually fallen in Indonesia in recent years. There has been an increase in government employees hired directly by regional governments, but their salaries are lower than those of PNS. It seems likely that the majority of those classified as middle class on Java in 2016 were in private-sector jobs, although this may not be the case outside of Java. For a detailed recent assessment of the Indonesian civil service, see Asian Development Bank 2021.

20 Post (2002) argues that it is likely that many Chinese during the Soeharto era were small traders and shopkeepers, whose incomes were unlikely to be much higher than their indigenous Indonesian counterparts. 
By the 1980s, it was clear that more than a decade of accelerated economic growth was creating new employment opportunities for well-educated people, especially in urban areas. An urban middle class was emerging whose consumption norms were becoming more oriented to those in high-income countries. By 1995, almost $10 \%$ of the Indonesian population was estimated to be in the 'urban upper-income group', and about one quarter of household disposable incomes accrued to this group. Over the next ten years, their share of both total population and income fell as a result of much slower economic growth. But in more recent years, it would appear that the size of the middle class has been growing, especially in urban Java. According to World Bank estimates, in 2016, there were 53.6 million Indonesians in the middle class and a further 114.7 million in the 'aspirational middle classes'. These were considerably larger numbers than those in the poor and vulnerable groups. How many of the middle class remain dependent on government budgets remains unclear, but it is likely that on Java in particular the middle class is now less dependent on government expenditures than in the 198 os.

The growth of the middle class, and those aspiring to middle-class status, brings problems as well as advantages. Middle-class consumption habits, especially regarding vehicle ownership, have led to more traffic congestion and environmental pollution, which hurts all sections of the population. GDP in 2020 contracted by over $2 \%$ as a result of the Covid-19 pandemic, and poverty and inequality may increase. As a result, the aspirational middle classes may face difficulties in moving upwards, and more people may be pushed into poverty. Perceptions of social disparities, especially in urban areas, could sharpen. Even in the context of reasonable economic growth over the next decade, those social groups who feel disadvantaged, at least in a relative sense, may vent their frustrations by supporting political parties that advocate more aggressive distributional policies. With more Indonesians now in the upperincome groups, there will be growing pressures from them for better government services, which may have to come at the expense of support for lowerincome groups, especially those in rural areas.

A policy of 'betting on the strong' is likely to gain more support when the relatively strong are in the majority, at least in urban areas. ${ }^{21}$ But as Wertheim

21 Dartanto, Moeis and Otsubo (2020:220), on the basis of their analysis of the decline in poverty and growth of the middle class from 1993 to 2014, argue that the middle class will dominate Indonesia's future policy agenda for development, and will be the 'backbone of the market economy and democracy'. These rather strong claims are not backed up by much evidence and were obviously written prior to the Covid-19 crisis. 
(1964:271) pointed out many years ago, such a policy can easily become one of 'the devil take the hindmost'. Indonesia has won much praise over the past two decades as a Muslim majority country that has established a functioning democracy in the context of improved living standards for the majority of the population. But a significant minority are still living in poverty or near poverty, and their numbers may grow again if growth slows. Addressing the different needs of the poor and the middle classes will be an ongoing challenge for future governments.

\section{References}

Albert, Jose Ramon G., Angelo G.F. Santos and Jana Flor V. Vizmanos (2018). Profile and determinants of the middle-income class in the Philippines. Quezon City: Philippine Institute of Development Studies. [Discussion Paper Series No. 2018-20.]

Anspach, Ralph (1969). 'Indonesia', in: Frank H. Golay, Ralph Anspach, M. Ruth Pfanner and Eliezar B. Ayal (eds), Underdevelopment and economic nationalism in Southeast Asia, pp. 111-201. Ithaca: Cornell University Press.

Asian Development Bank (2010). 'The rise of Asia's middle class', in: Asian Development Bank, Key indicators for Asia and the Pacific 2010, pp. 3-57. Mandaluyong City: Asian Development Bank.

Asian Development Bank (2021). A diagnostic study of the civil service in Indonesia. Metro Manila: Asian Development Bank.

Aspinall, Edward and Ward Berenschot (2019). Democracy for sale: Elections, clientelism, and the state in Indonesia. Ithaca and London: Cornell University Press.

Badan Pusat Statistik (2008). Sistem neraca sosial ekonomi Indonesia. Jakarta: Badan Pusat Statistik.

Badan Pusat Statistik (2019). Keadaan angkatan kerja di Indonesia (Labour force situation in Indonesia) August 2019. Jakarta: Badan Pusat Statistik.

Biro Pusat Statistik (1968). Statistical pocketbook of Indonesia 1964-1967. Jakarta: Biro Pusat Statistik.

Biro Pusat Statistik (1997). Keadaan angkatan kerja 1996 (Labour force situation in Indonesia 1996). Jakarta: Biro Pusat Statistik.

Booth, Anne (1988). Agricultural development in Indonesia. Sydney: Allen and Unwin for the Asian Studies Association of Australia.

Booth, Anne (1992). 'Income distribution and poverty', in: Anne Booth (ed.), The oil boom and after: Indonesian economic policy and performance in the Soeharto Era, pp. 323-62. Singapore: Oxford University Press.

Booth, Anne (1994). 'Repelita VI and the second long-term development plan', Bulletin of Indonesian Economic Studies 30-3:1-39. 
Booth, Anne (1998). The Indonesian economy in the nineteenth and twentieth centuries: A history of missed opportunities. Basingstoke: The Macmillan Press.

Booth, Anne (2000). 'Poverty and inequality in the Soeharto Era: An assessment', Bulletin of Indonesian Economic Studies 36-11:73-104.

Booth, Anne (2010). 'Splitting, splitting and splitting again: A brief history of the development of regional government in Indonesia since independence', Bijdragen tot de Taal-, Land- en Volkenkunde 167-1:31-59.

Booth, Anne (2016). Economic change in modern Indonesia: Colonial and post-colonial comparisons. Cambridge: Cambridge University Press.

Booth, Anne and R.M. Sundrum (1976). 'The 1973 agricultural census', Bulletin of Indonesian Economic Studies 12-2:90-105.

Booth, Anne and R.M. Sundrum (1981). 'Income distribution', in: Anne Booth and Peter McCawley (eds), The Indonesian economy during the Soeharto Era, pp.181-217. Kuala Lumpur: Oxford University Press.

Carroll, Toby (2020). 'The political economy of Southeast Asia's development from independence to hyperglobalisation', in: Toby Carroll, Shahar Hameiri and Lee Jones (eds), The political economy of Southeast Asia: Politics and uneven development under hyperglobalisation, pp. 35-84. Cham: Springer Nature for Palgrave Macmillan.

Castles, Lance (1965). 'Socialism and private business: The latest phase', Bulletin of Indonesian Economic Studies 1:13-45.

Dartanto, Teguh, Faizal R. Moeis and Shigeru Otsubo (2020). 'Intergenerational economic mobility in Indonesia: A transition from poverty to the middle class in 19932014', Bulletin of Indonesian Economic Studies 56-2:193-224.

Dick, H.W. (1985). 'The rise of the middle class and the changing concept of equity in Indonesia: An interpretation', Indonesia 39-4:71-92.

Downey, Roger Allen (1984). Indonesian inequality: Integrated national accounting of who gets what. Ann Arbor: University Microfilms International. [PhD dissertation, Cornell University; 2 vols.]

Eng, Pierre van der (2013). 'Historical national accounts data for Indonesia, 188o-2012'. Canberra: Australian National University. [Mimeo.]

Evers, Hans-Dieter (1987). 'The bureaucratization of Southeast Asia', Comparative Studies in Society and History 29-4:666-85.

Farid, Hilmar (2005). 'The class question in Indonesian social sciences', in: Vedi R. Hadiz and Daniel Dhakidae (eds), Socialscience and power in Indonesia, pp. 167-96. Jakarta and Singapore: Equinox Publishing (Asia) Pte. Ltd.

Geertz, Clifford (1963). Peddlers and princes: Social change and economic modernization in two Indonesian towns. Chicago: University of Chicago Press.

Gray, Clive (1979). 'Civil service compensation in Indonesia', Bulletin of Indonesian Economic Studies 15-1:85-113. 
Habir, Ahmad D. (1999). 'Conglomerates: All in the family', in: Donald K. Emmerson (ed.), Indonesia beyond Suharto, pp. 168-202. Armonk: M.E. Sharpe.

Kahin, George McTurnan (1952). Nationalism and revolution in Indonesia. Ithaca: Cornell University Press.

Kroef, Justus M. van der (1956). 'Entrepreneur and middle class', in: J.M. van der Kroef, Indonesia in the modern world. Part Two, pp. 1-61. Bandung: Masa Baru Ltd.

Kroef, Justus M. van der (1963). 'Peasant and land reform under Indonesian communism', Journal of Southeast Asian History 4-1:31-67.

Lev, Daniel S. (1990). 'Intermediate classes and change in Indonesia', in: Richard Tanter and Kenneth Young (eds), The politics of middle class Indonesia, pp. 25-43. Clayton: Center of Southeast Asian Studies, Monash University. [Monash Papers on Southeast Asia 19.]

Lindblad, J. Thomas (2010). 'Economic growth and decolonisation in Indonesia', Itinerario (European Journal of Overseas History) 34-1:97-111.

Mackie, J.A.C. (1990). 'Money and the middle class', in: Richard Tanter and Kenneth Young (eds), The politics of middle class Indonesia, pp. 96-122. Clayton: Center of Southeast Asian Studies, Monash University. [Monash Papers on Southeast Asia 19.]

McVey, Ruth (1982). 'The beamtenstaat in Indonesia', in: Benedict Anderson and Audrey Kahin (eds), Interpreting Indonesian politics: Thirteen contributions to the debate, pp. 84-91. Ithaca: Cornell Modern Indonesia Project. [Interim Report Series, Publication 62.]

Meijer Ranneft, J.W. and W. Huender (1926). Onderzoek naar de belasting druk op de Indische bevolking. Weltevreden: Government Printing.

Mertens, Walter (1978). 'Population census data on agricultural activities in Indonesia', Majalah Demografi Indonesia 9:9-53.

Mortimer, Rex (1982). 'Class, social cleavage and Indonesian communism', in: Benedict Anderson and Audrey Kahin (eds), Interpreting Indonesian politics: Thirteen contributions to the debate, pp. 54-68. Ithaca: Cornell Modern Indonesia Project. [Interim Report Series, Publication 62.]

Nugroho (1967). Indonesia: Facts and figures. Jakarta: Central Bureau of Statistics.

Pincus, Jonathan R. (1996). Class power and agrarian change. Basingstoke: Macmillan Press Limited.

Post, Peter (2002). 'The Kwik Hoo Tong Trading Society of Semarang, Java: A Chinese business network in late colonial Asia', Journal of Southeast Asian Studies 33-2:27996.

Robison, Richard (1986). Indonesia: The rise of capital. Sydney: Allen and Unwin.

Rodan, Garry and Jacqui Baker (2020). 'Explaining political regimes in Southeast Asia: A modes of participation framework', in: Toby Carroll, Shahar Hameiri and Lee Jones (eds), The political economy of Southeast Asia:Politics, and uneven development under hyperglobalisation, pp. 87-109. Cham: Springer Nature for Palgrave Macmillan. 
Schrieke, B.J.O. (1966). 'The causes and effects of communism on the west coast of Sumatra', as translated and reprinted in Indonesian sociological studies: Selected writings of B. Schrieke, pp. 85-166. The Hague: Van Hoeve.

Wertheim, W.F. (1956). Indonesian society in transition: A study of social change. Bandung: Sumur Bandung.

Wertheim, W.F. (1964). 'Betting on the strong', in: W.F. Wertheim, East-West parallels: Sociological approaches to modern Asia, pp. 259-77. The Hague: Van Hoeve.

White, Ben (2016). 'Remembering the Indonesian Peasants' Front and Plantation Workers' Union (1945-1966)', Journal of Peasant Studies 43-1:1-16.

Wicaksono, Agus (2020). 'Post-1998 changes in rural Java: The rapid expansion of the middle class', Southeast Asian Studies 9-3:351-80.

World Bank (2019). Aspiring Indonesia-Expanding the middle class. Washington: The World Bank.

World Bank (2020). Purchasing power parities and the size of world economies: Results from the 2017 International Comparison Program. Washington DC: International Bank for Reconstruction and Development/The World Bank. 